\title{
PROCEEDINGS
}

JOINT CONVENTION MALANG 2017, HAGI - IAGI - IAFMI- IATMI (JCM 2017)

Ijen Suites Hotel, Malang, September 25 - 28, 2017

\section{Iron Ore Mineralization Potential: A Case Study of Karimunjawa Islands, Central Java}

Sandy H.S. Herho ${ }^{l}$, Wahyu Dwijo Santoso ${ }^{2}$

${ }^{1}$ Meteorology Study Program, Faculty of Earth Sciences and Technology, Institut Teknologi Bandung

${ }^{2}$ Geological Engineering Study Program, Faculty of Earth Sciences and Technology, Institut Teknologi Bandung

Email: sandyherho@meteo.itb.ac.id

\begin{abstract}
Geological conditions of Karimunjawa Archipelago, particularly Karimunjawa and Kemujan, is still very rare to be investigated. Besides the potential of natural resources in these islands has never known and discussed in detail.

From the results of geological traverse at Karimunjawa and Kemujan exposed two rock formations, named Karimunjawa Formation and Parang Formation. Karimunjawa Formation lithology consists of Pre - Tertiary aged sandstone and slate. Parang Formation which exposed on the Kemujan consists of iron ore.

Iron ore in Kemujan was formed by residual process on volcaniclastic rocks in the Parang Formation. Iron ore outcrops are common in the northern part of in the Kemujan Island. Exposed iron ore classified into hematite groups. The calculation results of iron resources using deterministic methods show iron resources in Kemujan amounted to 36.000 ton.
\end{abstract}

\section{Introduction}

The Karimunjawa Islands is a cluster of small islands located in the north of the island of Java. Information about geological conditions of Karimunjawa Islands are still very limited and few. Previous research that discussed the regional geological conditions of Karimunjawa Islands had been done by Nayoan (1975) and Suparyanto et al. (2005). Lack of literature and knowledge about Karimunjawa geological conditions make any information about outcrop data becomes very valuable.

Furthermore, it turns that Karimunjawa Islands have potential iron ore mineralization that is still rarely known. Iron ore outcrops, which much exposed at eastern side of Karimunjawa Islands, are certainly interesting to be discussed, both from the aspect of scientific and economic aspects. Linkages between potential iron ore and geological conditions in Karimunjawa Islands would be interesting and should be understood to support exploration activities in the future.

\section{Regional Geology}

The study area is the Karimunjawa Islands, Jepara District, Central Java Province at coordinates $5^{\circ} 40^{\prime}-5^{\circ} 57^{\prime}$ South Latitude dan $110^{\circ} 04^{\prime}-110^{\circ} 40^{\prime}$ East Longitude (Figure 1). According Nayoan (1975), there are two exposed rock formations, named Karimunjawa Formation and Parang Formation. Karimunjawa Formation consists of coarse sandstones and conglomerates, phylitic shales and sand clay intercalations. Karimunjawa Formation exposure is present in Karimunjawa, Kemujan, Menjangan and Gundul islands. This rock groups is generally categorized as Pre Tertiary aged basement rocks, and it has been faulting intensively (Suparyanto et al., 2005). Parang Formation consists of basic lava flows and intrusive bodies, accompanied by volcaniclastics (Nayoan, 1975), has basaltic composition. Karimunjawa Formation unconformably overlain by this Parang Formation in Kemujan Island. Exposure was found in Parang, Nyamuk, Genting and Kemujan islands. Parang Formation consists of Holocene age rocks. Regional geologic map can be seen in Figure 2.

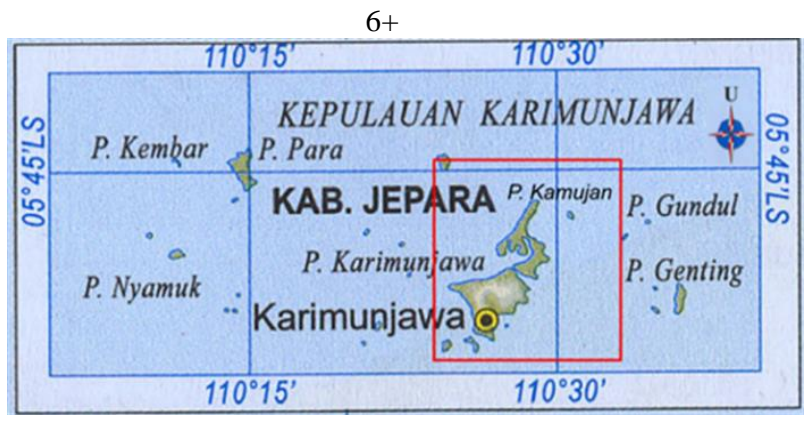

Figure 1. Karimunjawa Islands Map. Research area in red box.

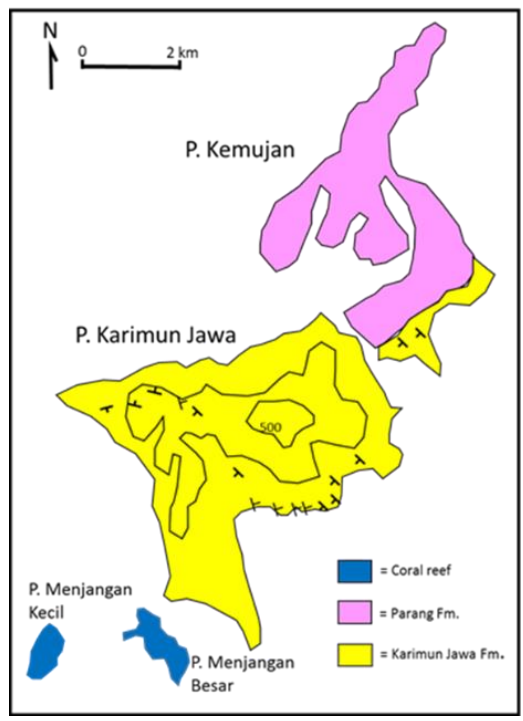

Figure 2. Karimunjawa and Kemujan Geologic Map (Modification from Nayoan,1975) 
PROCEEDINGS

JOINT CONVENTION MALANG 2017, HAGI - IAGI - IAFMI- IATMI (JCM 2017)

Ijen Suites Hotel, Malang, September 25 - 28, 2017

\section{Methods}

Construction of geological traverse conducted along the northern coast of the Kemujan Island and the west coast of the Karimunjawa Island (Figure 3). Aside from constructing traverse, sampling of rocks and iron ore was also conducted. Iron samples was analyzed in a chosen laboratory, named tekMIRA Laboratory located in Jalan Jenderal Sudirman 623, Bandung, West Java.

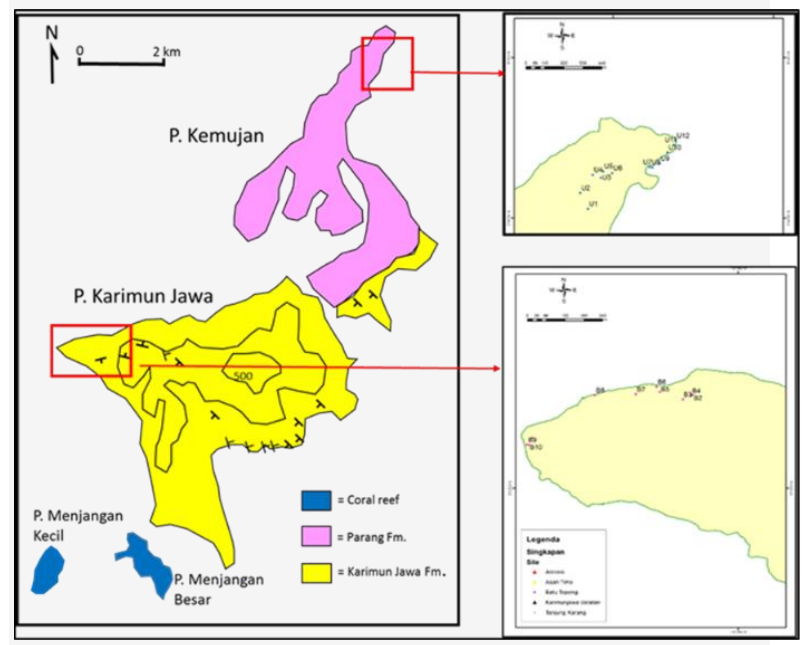

Figure 3. Traverse and Sampling Map

\section{Results}

From geological traverse along the western coast of Karimunjawa Island, outcrops of quarzite sandstones and slates were encountered. Quartzite sandstones outcrop are still in fresh condition, and sedimentary structure such as cross bedding and parallel lamination can be observed (Figure 4). Quartzite sandstone lithology is characterized by white colour, rounded, well sorted, grain supported and the presence of quartz and mica minerals. The presence of a lot of micaceous minerals which have foliation structure indicates the sandstones started being metamorphosed. Besides quartzite sandstones, it also found slate outcrops that still a fairly clear bedding. Slate outcrop is characterized by red colour, slatty foliation and micaceous minerals orientation (Figure 5). Common lithologic characteristics, which are observed in the field, showed that traverse is categorized as Karimunjawa Formation (Nayoan, 1975). From the observation of this traverse, the outcrops that containing iron ore were not encountered.

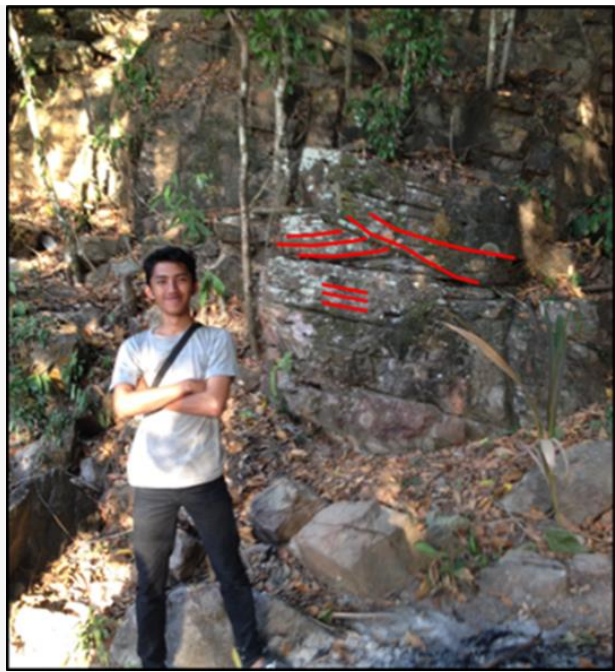

Figure 4. Outcrop of Sandstone, Karimunjawa Formation

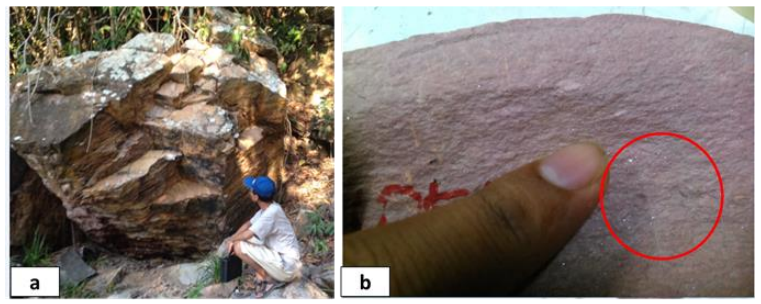

Figure 5. (a) Slate Outcrop which still shows laminated impression (b). Micaceous mineral ( red circle ) contained in slate sample.

Iron ore outcrops are often found along the road on the north coast of Kemujan. The exposed iron ore is characterized by following characteristics, colour that characterizes medium - strong magnetic, outcrops are commonly found in boulder forms, boulders within relative large size with a diameter of about $1 \mathrm{~m}$, there is a cavity structures (Figure 6). Cavity structures in some parts filled with gravels in the form of quartz, lithic and coral fragments. Iron ore boulders and outcrop are spread well in the northern part of Kemujan. Based on Nayoan (1975), iron ore outcrops belong to Parang Formation. 


\section{PROCEEDINGS}

JOINT CONVENTION MALANG 2017, HAGI - IAGI - IAFMI- IATMI (JCM 2017)

Ijen Suites Hotel, Malang, September 25 - 28, 2017

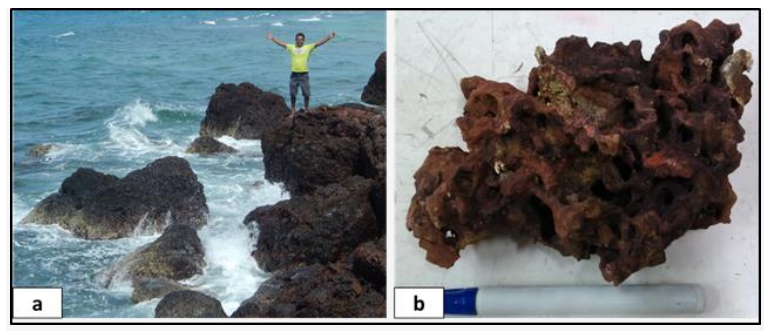

Figure 6. (a) Iron Ore Outcrops on the Kemujan Island. (b) Sample of Iron Ore from the Kemujan Island.

Iron ore which found in Kemujan is associated with volcaniclastics (Nayoan, 1975). Iron ore is formed due to magmatism and hydrothermal process in basalt magma that occurred in Holocene age. Basalt magma containing hydrothermal solutions break through volcaniclastic rocks from Parang Formation that resulted partial cementation by iron ore. The weathering process that had been occurring continuously had been made by separating iron ore from volcaniclastic rocks. The remaining volcaniclastic rocks eroded and carried by the water, leaving a residual iron ore by type. The natural characteristic of the iron ore is immobile. When it happens washing process which resulted the iron ore is left behind near the country rock. Iron ore found in weathered soils and boulders contains iron resulted from the washing process. The process of formation of iron ore in the Kemujan Island can be seen in Figure 7.

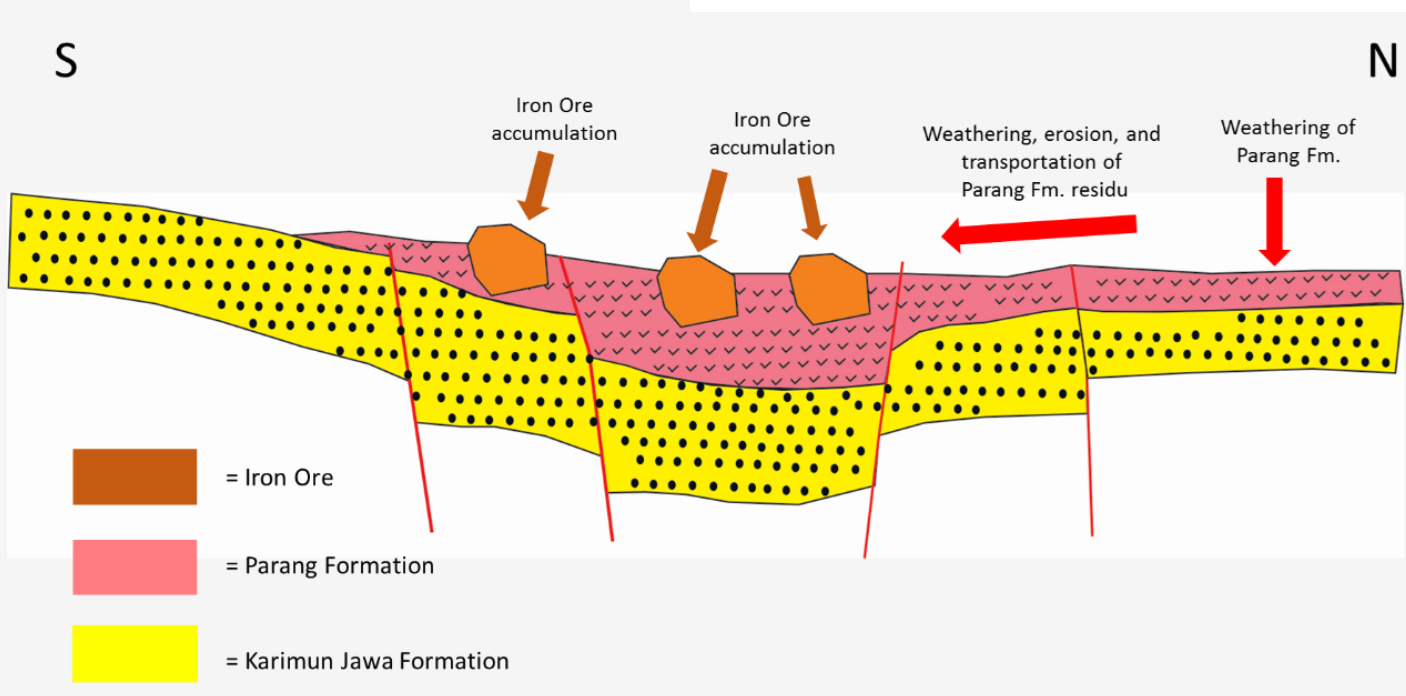

Figure 7.The Concept of Iron Ore Formation in the Kemujan Island

(Model was inspired by Torres-Ruiz, J., 2006) 
PROCEEDINGS

JOINT CONVENTION MALANG 2017, HAGI - IAGI - IAFMI- IATMI (JCM 2017)

Ijen Suites Hotel, Malang, September 25 - 28, 2017

From the iron ore grade analysis, it was found that the total Fe content are on the three samples were analyzed ranged between $44.7 \%$ - 54.2\% . For Fe2O3, the analized sample was on the range between $50 \%-50.5 \%$. Based on field descriptions and the content of $\mathrm{Fe}$ and $\mathrm{Fe} 2 \mathrm{O} 3$, iron ore in Kemujan can be classified as Hematite (Jensen and Bateman, 1981).

Deterministic resource calculation process is performed to determine the potential for iron ore deposits in the Kemujan. Iron ore outcrops are map can be seen in Figure 8. On this calculation, the thickness of iron ore is assumed $10 \mathrm{~m}$. this thickness is assumed to be equal to whole area there are exposed. This assumption was measured in outcrop exposed by both the cliffs and can be measured. Resources calculation refers to Pedoman Teknis Eksplorasi Pasir Besi (2005), using the following equation:

$$
C=L \times t \times M G \times S G
$$

$C=$ Resources $($ ton $)$

$L=$ Area of influence $\left(\mathrm{m}^{2}\right)$

$t=$ Average thickness of iron sands deposits ( $\mathrm{m}$ )

$M D=$ The percentage of magnetism ( \% )

$S G=$ Specific gravity $\left(\right.$ ton $\left./ \mathrm{m}^{3}\right)$

From the data, we obtained, $L=2000 \mathrm{~m}^{2}, t=10 \mathrm{~m}, M D=$ $50 \%$, and $S G=3.6 \mathrm{ton} / \mathrm{m}^{3}$ (due to the type of iron deposits in Kemujan, that is hematite), then known iron ore resources in Kemujan weight by 36.000 ton.

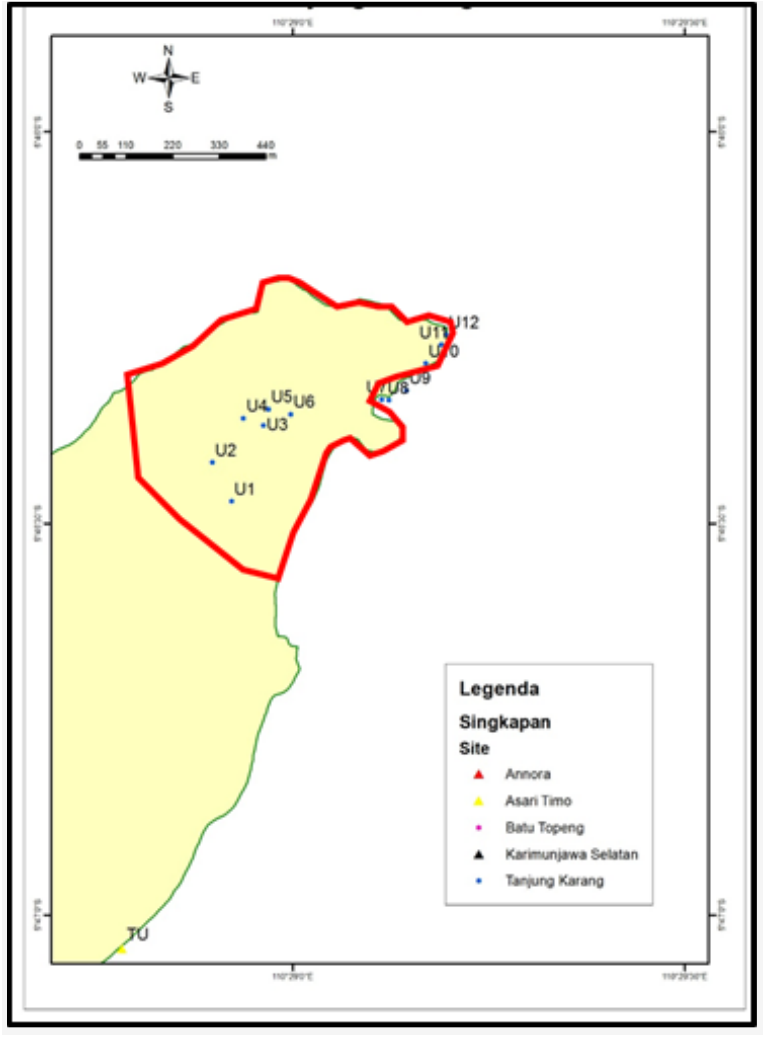

Figure 8. Iron Ore Outcrop Occurrences Area. The Total Area (red box) by $2000 \mathrm{~m}^{2}$.

\section{Conclusions}

Rocks exposed in the Karimunjawa and Kemujan consists of sandstone and slate from Karimunjawa Formation and iron ore from Parang Formation. Iron ore from Parang Formation found along the northern coast of the Kemujan Island thats relatively found in boulder forms with diameter around $1 \mathrm{~m}$. Iron ore of Kemujan Island is residual type resulted from weathering process of source rock that derived from volcaniclastic rocks. Volcaniclastic rocks could be mineralized because the breakthrough of Holocene aged basaltic magma.

The results of chemical analysis of iron ore in Kemujan Island contain total $\mathrm{Fe}$ around $44.7 \%-54.2 \%$ and $\mathrm{Fe}_{2} \mathrm{O}_{3}$ around $50 \%-56.5 \%$. Field observations and laboratory and laboratory analysis indicates that the iron ore in Kemujan Island is classified as hematite. Calculation of resources using deterministic methods show iron resources in Kemujan amounted to 36.000 ton. 


\section{PROCEEDINGS}

JOINT CONVENTION MALANG 2017, HAGI - IAGI - IAFMI- IATMI (JCM 2017)

Ijen Suites Hotel, Malang, September 25 - 28, 2017

\section{Discussion}

Kemujan Island has great potential for iron ore. To determine the size of iron ore reserves, it is neccesary to do the geological mapping with a wider area, making test pit, using geophysical methods to determine the thickness of iron ore and more abundant with more systematically sampling, so we get more accurate results.

\section{References}

Jensen, M.L. and Bateman, A.M. (1981). Economic Mineral Deposits. New York: John Wiley and Sons.

Nayoan, G.A.S., 1975, Majalah Geologi Indonesia, 2 (2), 13-20.

Suparyanto, Igna Hadi, Hartanto, Priyo, Maria, Rizka, Sukmayadi, Hadi, Sodik,A.. (2005) Studi Sumberdaya Air Pulau Karimunjawa. Bandung: Pusat Penelitian Geoteknologi LIPI.

Tim Direktorat Inventarisasi Sumber Daya Mineral. (2005). Pedoman Teknis Eksplorasi Pasir Besi. Jakarta: Pusat Sumberdaya Geologi.

Torres-Ruiz, J., 2006, Economic Geology, 101, 667-677.

\section{Acknowledgements}

We would like to thank all the colleagues that we have had the pleasure and honor to work with in the field at Karimunjawa and Kemujan, as well as those who helped prepare and analyze rocks, minerals, and data in tekMIRA Laboratory. 